\title{
Penconazole Induced Heat Tolerance in Scots Pine (Pinus sylvestris) and Evergreen Oak (Quercus ilex)
}

\author{
Glynn C. Percival and Kelly Noviss
}

\begin{abstract}
The ability of penconazole, a triazole fungicide derivative, to protect against and ameliorate heat stress was studied in evergreen oak (Quercus ilex) and Scots pine (Pinus sylvestris). Under laboratory conditions, heat damage to the leaf photosynthetic system based on the stability of the chlorophyll a/b light-harvesting complex within photosystem II (chlorophyll fluorescence Fo responses) and leaf photochemical efficiency (chlorophyll fluorescence $\mathrm{Fv} / \mathrm{Fm}$ emissions) of detached leaves was constantly less in penconazole treated trees. In both species, greatest protection of the leaf photosynthetic system to heat induced disorders was achieved by application of penconazole at a concentration of $30 \mathrm{~g}$ per liter of water compared to penconazole applied at a concentration of 0.15 or $0.45 \mathrm{~g}$ per liter of water. Subjecting containerized trees of both species to 10 minutes at $50^{\circ} \mathrm{C}$ significantly reduced tree vitality with respect to chlorophyll fluorescence Fo and Fv/Fm emissions, total foliar chlorophylls, leaf photosynthetic rates (Pn) and significantly increased damage to cellular membrane integrity as manifest by higher leaf electrolyte leakage and visual leaf necrosis between stressed and non-heat stressed well-watered trees. The influence of penconazole applied immediately after heat stress on the pattern of recovery over the following twelve weeks demonstrated penconazole treated trees were the most capable of recovery. With respect to chlorophyll fluorescence Fo and leaf electrolyte leakage values recovery rates of heat damaged trees treated with penconazole ranged from 20\%-50\% higher than non-triazole treated control trees. In all cases non-penconazole treated control trees had the least capacity for recovery. Regardless of species, height, leaf area, root, shoot, and total plant dry weight were, in virtually all instances, greater than non-penconazole treated controls. The tactical use of the triazole derivative penconazole as an ameliorant against heat damage and recovery from heat stress in Scots pine and evergreen oak would be of benefit to improve tree recovery rates and growth. From a practical point of view penconazole at $30 \mathrm{~g}$ a.i. per liter of water is suggested based on the results of this study.

Key Words. Chlorophylls; Chlorophyll Fluorescence; Electrolyte Leakage; Fungicides; Growth Inhibitor; Physiogenic Stress; Stress Enzymes.
\end{abstract}

Higher temperatures in urban environments caused by the lack of transpirational cooling, heat convection, and long wave radiation from nonvegetative surfaces (e.g., buildings, roads) can be detrimental to the biology of trees (Kolb and Robberecht 1996; Ladjal et al. 2000). Under prolonged heat stress, high temperature injury is primarily manifest by leaf and wood desiccation inducing water stress throughout the canopy (Sprugel et al. 1991). With prolonged desiccation, tree limbs and trunks can break and shed prematurely; a phenomenon known as summer branch drop, which appears to be linked to internal water stress (Harris et al. 2004). Such a response is undesirable in highly populated urban areas. Photosynthesis is one of the most heat-sensitive processes in plant cells, leading to numerous changes within the structure and function of the photosynthetic apparatus (Georgieva et al. 2000). Within the photosynthetic system it has been recognized that photosystem II (PSII) is the most thermally liable component of the electron transport chain (Cajanek et al. 1998). Among partial reactions of PSII, the oxygen evolving complex is particularly heat sensitive (Georgieva et al. 2000). As higher rates of photosynthesis are recognized as a physiological characteristic conferring robustness during periods of stress, a reduction in leaf photosynthetic rates, or damage to the leaf photosynthetic system can reduce leaf photosynthetic productivity (Percival 2005). Consequently, heat stress can limit the amount of carbohydrates available for growth and maintenance, and subsequently reduce nutri- ent and water uptake resulting in leaf chlorosis, dieback, and plant death (Georgieva et al. 2000; Ladjal et al. 2000; Percival et al. 2006). Drought conditions recorded in 2003, 2004, and 2006 coupled with hose pipe bans in the South of England, and most climate models predicting hotter drier summers for the $\mathrm{UK}$, have meant heat-related tree disorders may become even more prominent within urban landscapes (Percival et al. 2006). Improving hardiness against heat stress may ensure greater post-planting survival of newly-planted trees and increase longevity of established ones. Consequently, finding exogenous chemicals that enhance tree stress tolerance may prove important under prolonged heat conditions (Still and Pill 2004).

Penconazole forms the active ingredient of a triazole fungicide commonly used within the horticultural, agricultural, and forestry industries for foliar pathogen control (Kenyon et al. 1997; Schnabel and Parisi 1997). Fungicidal properties are via inhibition of the C4-demethylase reactions in fungal sterol biosynthesis (Allingham 2005). However, many triazole based fungicides such as penconazole have been shown to induce a suite of morphological and physiological adaptations that allow plants to tolerate a broad range of environmental stresses to include drought, herbicide, and elevated temperatures (Fletcher et al. 1986; Kraus and Fletcher 1994; Jaleel et al. 2006; Percival and Noviss 2008). Most studies have focused on the growth inhibitor paclobutrazol as a pre-stress treatment to protect plants against drought, herbicide and waterlogging (Asare-Boamah et al. 1986; 
Fletcher et al. 2000; Marshall et al. 2000). Paclobutrazol-induced reductions in plant growth are well documented (Watson 2001). Paclobutrazol blocks gibberellic acid biosynthesis, more specifically the pathway at the ent-kaureno oxidation stage. Two to three-year growth over-regulation has been associated with PBZ applications that may be undesirable for landscape planting where aesthetics are a major factor regarding tree selection (Fletcher et al. 2000; Percival 2008). Such long-term over-regulatory growth responses are not associated with penconazole. The influence of penconazole on enhancing the heat tolerance of woody plants has received limited investigation. Consequently, the aims of this study were:

* To determine the effectiveness of penconazole applied as a foliar spray at a range of concentrations on improving the foliar heat tolerance of evergreen oak (Quercus ilex) and Scots pine (Pinus sylvestris) under laboratory conditions using detached leaf material.

* To determine the ability of penconazole to aid whole tree recovery from heat-induced damage.

\section{MATERIALS AND METHODS}

\section{Plant Material}

Evergreen oak and Scots pine were selected for experimental purposes because of their importance in the amenity and forestry industry respectively. Four-year-old cell grown stock $c a .103 .5 \pm$ $15.4 \mathrm{~cm}$ and $110.0 \pm 11.3 \mathrm{~cm}$ high were used (Alba Trees, Lower Winton, East Lothian, Scotland). Six months prior to experiments trees were potted into 10 liter plastic pots filled with loam soil ( $24 \%$ clay, $45 \%$ silt, $31 \%$ sand, $3.1 \%$ organic carbon, $\mathrm{pH} 6.2$ ), supplemented with the controlled release N:P:K (29:7:9) fertilizer (Bartlett BOOST, The Doggett Corporation, Lebanon, New Jersey, U.S.) at $1 \mathrm{~g}$ per $\mathrm{kg}$ of soil. Following potting, trees remained outdoors subject to natural environmental conditions and watered as required. Studies were conducted at Reading University, Earley Gate research site glasshouses $\left(51^{\circ} 43 \mathrm{~N},-1^{\circ} 08 \mathrm{~W}\right)$.

\section{Triazole Application}

Foliar sprays of penconazole (Trade name Topas, United AgriProducts, Alconbury Weston, Huntingdon, UK) were applied until runoff ( $c a .50 \mathrm{ml}$ per tree) using a hand-held sprayer. The influence of concentration was determined by spraying 10 trees at $0.15,0.30$, or $0.45 \mathrm{~g}$ active ingredient per liter of water. Ten trees were sprayed once at each concentration. Nontriazole-treated trees acted as controls. Plants were left for two weeks under glasshouse conditions $\left(22 \pm 2^{\circ} \mathrm{C}\right)$, supplemented with 400W SON/T high pressure sodium lamps (TLC Electrical, St Philips, Bristol, UK), providing a 16 hour photoperiod and minimum $250 \mu \mathrm{mol} \mathrm{m} \mathrm{m}^{-2} \mathrm{~s}^{-1}$ photosynthetically active radiation at the tree crown to promote absorption and uptake of each triazole derivative. During this period, plants were watered until container runoff generally every three days.

\section{Foliar Tolerance to Heat Stress Under Laboratory Conditions}

At week 2 after spraying, five fully expanded nonsenescing leaves per tree were excised at the base of the petiole using a razor blade and placed abaxial surface down, in a petri dish on moist Watmans filter paper sealed with a thin polythene film permeable to air but not water prior to placing in darkness in a Merck Environmental Growth Chamber for 5, 10, 15, and 20 minutes at a temperature of $50^{\circ} \mathrm{C}$.All leaf material was prepared within two hours of collection.

\section{Recovery of Containerized Trees from Heat Stress}

Heat stress was induced by placing containerized stock in a Merck Environmental Growth Chamber for 10 minutes at a temperature of $50^{\circ} \mathrm{C}$. At the cessation of the heat period a number of physiological measurements were made on leaf tissue to measure tree vitality. Immediately following these measurements, trees were sprayed until run-off with penconazole at $0.15,0.30$, or 0.45 $\mathrm{g}$ active ingredient per liter of water. Ten trees were sprayed once at each concentration. Nontriazole treated trees acted as controls. Trees were then placed outdoors subject to natural weather conditions. Recovery rates were measured at three weekly intervals (June 26, July 17, August 7, August 28) over a 12-week period, and growth recorded at week 12 (August 28). A well-watered group of non-heat stressed trees were used for comparative evaluation of tree vitality and growth under outdoor conditions.

\section{Tree Vitality Measurements}

All vitality measurements were taken on leaf material present on the plant at the initiation of the experiment (existing leaves). During recovery from heat induced damage new leaf formation was observed at $c a$. weeks 6-7 on both nonpenconazole-treated control and penconazole-treated trees. No tree vitality measurements were taken on any newly formed leaf tissue (i.e., new leaves not present at the time of triazole application). If abscission or mortality of tagged leaves occurred the nearest adjacent leaf was tagged for future measurements. At each sampling date, five leaves per tree selected throughout the crown were used for chlorophyll fluorescence and chlorophyll content measurements. Leaves were then tagged to ensure the same leaf was measured throughout the study.

\section{Chlorophyll Fluorescence}

Chlorophyll fluorescence was used as a measure of damage to the leaf photosynthetic system. Leaves were adapted to darkness for 30 minutes by attaching light exclusion clips to the leaf surface and chlorophyll fluorescence was measured using a HandyPEA portable fluorescence spectrometer (Hansatech Instruments Ltd, King's Lynn, UK). Measurements were recorded up to 1 second with a data acquisition rate of $10 \mu$ s for the first two milliseconds and of one millisecond thereafter. The fluorescence responses were induced by a red (peak at $650 \mathrm{~nm}$ ) light of $1500 \mu \mathrm{mol} \mathrm{m} \mathrm{m}^{-2} \mathrm{~s}^{-1}$ PAR intensity provided by an array of six light emitting diodes. The ratio of variable $(\mathrm{Fv}=\mathrm{Fm}-\mathrm{Fo})$ to maximal $(\mathrm{Fm})$ fluorescence (i.e., $\mathrm{Fv} / \mathrm{Fm}$ where $\mathrm{Fo}=$ minimal fluorescence), of dark-adapted leaves was used to quantify the detrimental effects of heat on leaf tissue. Fv/Fm is considered a quantitative measure of the maximal or potential photochemical efficiency or optimal quantum yield of photosystem II (Willits and Peet 2001). Likewise Fv/Fm values are the most popular index used as a measure of plant vitality and early diagnostic of stress (Maxwell and Johnson 2001). Alterations with Fo values in leaf tissue are associated with dissociation of the light-harvesting chlorophyll $\mathrm{a} / \mathrm{b}$ complexes from the reaction centre complex of photosystem II and/or alterations to the xanthophyll cycle-dependent nonradiative energy dissipation process (Hong and Xu 1999; Yamane et al. 2000). 


\section{Leaf Chlorophyll Concentration}

Chlorophyll was extracted from leaf samples by suspending $1 \mathrm{~g}$ of fresh laminar tissue in $5 \mathrm{ml} 80 \% \mathrm{v} / \mathrm{v}$ aqueous acetone. After centrifugation at $2000 \mathrm{~g}$ for two minutes in closed vials, an aliquot of the supernatant was transferred to a $1 \mathrm{~cm}$ path glass cuvette and chlorophylls $a$ and $b$ calculated according to the equations of Lichtenthaler and Wellburn (1983), following measurement of absorbance at 663 and $645 \mathrm{~nm}$ in a spectrophotometer (PU8800 Pye Unicam, Portsmouth, UK).

\section{Photosynthetic $\mathrm{CO}_{2}$ Fixation (Pn)}

Light-induced $\mathrm{CO}_{2}$ fixation $(\mathrm{Pn})$ was measured in two pre-darkened (20 minutes) fully expanded leaves per tree near the top of the canopy (generally about the fourth leaf from the apex), using an Infra Red Gas Analyser (LCA-2 ADC, BioScientific Ltd, Hoddesdon, Herts, United Kingdom). The irradiance on the leaves was 700$800 \mu \mathrm{mol} \mathrm{m}{ }^{-2}$ PAR saturating with respect to Pn; the velocity of the airflow was $1 \mathrm{ml} \mathrm{s}^{-1} \mathrm{~cm}^{-2}$ leaf area. Calculation of the photosynthetic rates was carried out according to Von Caemmerer and Farquhar (1981). All photosynthetic measurements were taken in the early morning between 8:00-10:00 am on clear or partly cloudy days.

\section{Leaf Necrosis}

Leaf necrosis was assessed visually. Each tree was rated on a $0-5$ rating scale, using a visual indexing technique and ratings on the scale: $0=$ No necrosis observed; $1=$ less than $5 \%$ of leaves affected and no aesthetic impact; $2=5 \%-20 \%$ of leaves affected with some chlorosis but little or no defoliation; $3=21 \%-50 \%$ of leaves affected, significant defoliation and/or leaf chlorosis; $4=51 \%-80 \%$ of leaves affected, severe foliar discoloration; $5=81 \%-100 \%$ of foliage affected with $90 \%-100 \%$ defoliation.

\section{Leaf Electrolyte Leakage}

Quantitative heat damage to leaf tissue was assessed by measuring electrolyte leakage of entire leaves (two leaves per tree) at each sampling date. Excised leaves were placed in $50 \mathrm{ml}$ Universal bottles containing $30 \mathrm{ml}$ distilled water and gently shaken by hand. Samples were stored at $22^{\circ} \mathrm{C}$ for 24 hours in darkness prior to conductivity measurements using a Jenway conductivity probe and M4070 meter (BDH, Leicestershire, Loughborough, UK). Total solute leakage was obtained by autoclaving the leaf samples for one hour at $121^{\circ} \mathrm{C}$ and $0.103 \mathrm{MPa}$. Results are presented as percent of total solute leakage after 24 hours (McKay 1992).

\section{Growth}

At the cessation of each experiment trees were destructively harvested and leaf, shoot and root dry weight were recorded after oven drying at $85^{\circ} \mathrm{C}$ for 48 hours. Height was recorded by measuring the distance from the tip of the leading apical shoot to the soil surface. Leaf area size was quantified using a Delta-T leaf area meter (Delta-T Devices Ltd, Cambridge, UK).

\section{Experimental Design and Statistical Analysis}

The experimental design used was a Completely Randomized Block Design (CRBD) in which pots were re-randomized on a weekly basis. Ten trees per treatment were used at $1.5 \mathrm{~m}$ spacing to prevent competition for light. Data was analyzed by one- way ANOVA using the Genstat V program for Windows. Prior to the analysis data were examined for normality and homogeneity of variance (Levene 1960) and data were transformed [log $(y+0.5)]$ when necessary. Significant differences between means were separated by LSD test $(P<0.05)$. Visual leaf necrosis were analyzed after appropriate statistical transformation $\left[\arcsin \left(\mathrm{x}^{0.5}\right)\right]$.

\section{RESULTS}

\section{Foliar Tolerance to Heat Stress Under Laboratory Conditions}

In both tree species and at all four sampling times $(5,10,15$, 20 minutes) damage to the leaf photosynthetic system based on the stability of the chlorophyll $\mathrm{a} / \mathrm{b}$ light-harvesting complex within photosystem II (chlorophyll fluorescence Fo responses) and leaf photochemical efficiency (chlorophyll fluorescence $\mathrm{Fv} / \mathrm{Fm}$ emissions) was constantly less in penconazole-treated trees, indicating a positive influence of penconazole on enhancing foliar tissue tolerance to prolonged heat exposure (Tables $1-4)$. In the case of Scots pine the heat tolerance of leaf tissue was enhanced 14\%-21\% (Fo) and $11 \%-45 \%$ (Fv/Fm) when averaged over a twenty-minute heat exposure period (Tables 1-2). In the case of evergreen oak, the heat tolerance of leaf tissue was enhanced $12 \%-30 \%$ (Fo) and $27-46 \%$ (Fv/ Fm) when averaged over a twenty-minute heat exposure period (Tables 3-4) compared to nonpenconazole-treated controls.

Table 1. The influence of prolonged temperature exposure $\left(50^{\circ} \mathrm{C}\right)$ on stability of the chlorophyll $a / b$ lightharvesting complex within photosystem II based on chlorophyll fluorescence Fo responses within leaf tissue of Evergreen oak (Quercus ilex).

\begin{tabular}{llllll}
\hline Treatment & $0 \mathrm{~min}$ & $5 \mathrm{~min}$ & $10 \mathrm{~min}$ & $15 \mathrm{~min}$ & $20 \mathrm{~min}$ \\
Control & $238 \mathrm{a}$ & $589 \mathrm{~d}$ & $645 \mathrm{c}$ & $633 \mathrm{c}$ & $688 \mathrm{~b}$ \\
$0.15 \mathrm{~g}$ & $240 \mathrm{a}$ & $446 \mathrm{bc}$ & $564 \mathrm{bc}$ & $561 \mathrm{bc}$ & $632 \mathrm{ab}$ \\
$0.30 \mathrm{~g}$ & $258 \mathrm{a}$ & $333 \mathrm{ab}$ & $451 \mathrm{ab}$ & $493 \mathrm{a}$ & $570 \mathrm{a}$ \\
$0.45 \mathrm{~g}$ & $229 \mathrm{a}$ & $427 \mathrm{bc}$ & $475 \mathrm{ab}$ & $577 \mathrm{bc}$ & $610 \mathrm{ab}$ \\
\hline
\end{tabular}

Lower case letters indicate significant differences between means for each evaluation date by $\operatorname{LSD}(P=0.05)$

All values mean of ten trees, five leaves per tree.

Table 2. The influence of prolonged temperature exposure $\left(50^{\circ} \mathrm{C}\right)$ on photochemical efficiency within leat tissue of Evergreen oak (Quercus ilex) based on chlorophyll fluorescence $\mathrm{Fv} / \mathrm{Fm}$ responses.

\begin{tabular}{llllll}
\hline Treatment & $0 \mathrm{~min}$ & $5 \mathrm{~min}$ & $10 \mathrm{~min}$ & $15 \mathrm{~min}$ & $20 \mathrm{~min}$ \\
Control & $0.798 \mathrm{a}$ & $0.405 \mathrm{a}$ & $0.251 \mathrm{a}$ & $0.237 \mathrm{a}$ & $0.086 \mathrm{a}$ \\
$0.15 \mathrm{~g}$ & $0.799 \mathrm{a}$ & $0.564 \mathrm{~b}$ & $0.378 \mathrm{bc}$ & $0.335 \mathrm{bc}$ & $0.102 \mathrm{a}$ \\
$0.30 \mathrm{~g}$ & $0.772 \mathrm{a}$ & $0.682 \mathrm{bc}$ & $0.483 \mathrm{~cd}$ & $0.433 \mathrm{c}$ & $0.223 \mathrm{c}$ \\
$0.45 \mathrm{~g}$ & $0.785 \mathrm{a}$ & $0.579 \mathrm{~b}$ & $0.452 \mathrm{~cd}$ & $0.317 \mathrm{ab}$ & $0.167 \mathrm{~b}$ \\
\hline
\end{tabular}

Lower case letters indicate significant differences between means for each evaluation date by $\operatorname{LSD}(P=0.05)$.

All values mean of ten trees, five leaves per tree.

In the majority of cases, these increases in heat tolerance were significant at $P<0.05$ (Tables $1-2$ ). A significant influence of species and concentration of penconazole applied was recorded with respect to Fo and Fv/Fm (Table 5). Such a response is reflected in the results where the effects of heat stress had greater detrimental impacts on foliar tissue of evergreen oak compared to 
Scots pine for the first 10 minutes. Fo and Fv/Fm values at sampling times 15 and 20 minutes, however, indicated greater detrimental impacts on foliar tissue of Scots pine compared to evergreen oak (Table 1-4). Such a response indicates Scots pine may be able to better cope with heat stress over a short time period (up to 10 minutes), while evergreen oak superior over a prolonged period of intense heat (10-20 minutes). Irrespective of species, greatest protection of the leaf photosynthetic system to heat in-

Table 3. The influence of prolonged temperature exposure $\left(50^{\circ} \mathrm{C}\right)$ on stability of the chlorophyll $a / b$ lightharvesting complex within photosystem II based on chlorophyll fluorescence Fo responses within leaf tissue of Scots pine (Pinus sylvestris).

\begin{tabular}{llllll}
\hline Treatment & $0 \mathrm{~min}$ & $5 \mathrm{~min}$ & $10 \mathrm{~min}$ & $15 \mathrm{~min}$ & $20 \mathrm{~min}$ \\
Control & $90.3 \mathrm{a}$ & $152.7 \mathrm{a}$ & $218 \mathrm{c}$ & $290.4 \mathrm{~b}$ & $314 \mathrm{a}$ \\
$0.15 \mathrm{~g}$ & $89.7 \mathrm{a}$ & $155.7 \mathrm{a}$ & $205 \mathrm{bc}$ & $243.4 \mathrm{ab}$ & $303 \mathrm{a}$ \\
$0.30 \mathrm{~g}$ & $82.0 \mathrm{a}$ & $120.0 \mathrm{a}$ & $145 \mathrm{a}$ & $209.6 \mathrm{a}$ & $298 \mathrm{a}$ \\
$0.45 \mathrm{~g}$ & $85.8 \mathrm{a}$ & $127.6 \mathrm{a}$ & $156 \mathrm{a}$ & $236.2 \mathrm{ab}$ & $299 \mathrm{a}$ \\
\hline
\end{tabular}

Lower case letters indicate significant differences between means for each evaluation date by $\operatorname{LSD}(P=0.05)$.

All values mean of ten trees, five leaves per tree.

Table 4. The influence of prolonged temperature exposure $\left(50^{\circ} \mathrm{C}\right)$ on photochemical efficiency within leaf tissue of Scots pine (Pinus sylvestris) based on chlorophyll fluorescence Fv/ Fm responses.

\begin{tabular}{llllll}
\hline Treatment & $0 \mathrm{~min}$ & $5 \mathrm{~min}$ & $10 \mathrm{~min}$ & $15 \mathrm{~min}$ & $20 \mathrm{~min}$ \\
Control & $0.825 \mathrm{a}$ & $0.583 \mathrm{a}$ & $0.429 \mathrm{a}$ & $0.158 \mathrm{a}$ & $0.043 \mathrm{a}$ \\
$0.15 \mathrm{~g}$ & $0.816 \mathrm{a}$ & $0.645 \mathrm{abc}$ & $0.446 \mathrm{a}$ & $0.194 \mathrm{a}$ & $0.067 \mathrm{a}$ \\
$0.30 \mathrm{~g}$ & $0.818 \mathrm{a}$ & $0.702 \mathrm{c}$ & $0.595 \mathrm{~b}$ & $0.358 \mathrm{c}$ & $0.100 \mathrm{~b}$ \\
$0.45 \mathrm{~g}$ & $0.823 \mathrm{a}$ & $0.680 \mathrm{bc}$ & $0.507 \mathrm{a}$ & $0.295 \mathrm{~b}$ & $0.056 \mathrm{a}$ \\
\hline
\end{tabular}

Lower case letters indicate significant differences between means for each evaluation date by $\operatorname{LSD}(P=0.05)$

All values mean of ten trees, five leaves per tree.

Table 5. P values for chlorophyll fluorescence Fo and Fv/Fm following penconazole treatment. $P<0.05$ are considered significant.

\begin{tabular}{lll}
\hline & Fo & Fv/Fm \\
\hline Species (S) & $<0.001$ & 0.008 \\
Concentration (C) & $<0.001$ & $<0.001$ \\
S x C & $<0.001$ & $<0.001$ \\
\hline
\end{tabular}

duced disorders was achieved by application of penconazole at $30 \mathrm{~g}$ per liter of water compared to penconazole applied at 0.15 and $0.45 \mathrm{~g}$ per liter of water (Tables $1-4)$. In this instance all tree vitality measurements were greater than nontriazole-treated controls and penconazole applied at 0.15 and $0.45 \mathrm{~g}$ per liter of water.

\section{Recovery of Containerized Trees from Heat Stress}

Subjecting containerized trees of both species to 10 minutes at $50^{\circ} \mathrm{C}$ significantly reduced tree vitality with respect to chlorophyll fluorescence Fo and Fv/Fm emissions, total foliar chlorophylls, leaf photosynthetic rates (Pn) and significantly increased damage to cellular membrane integrity as manifest by higher leaf electrolyte leakage and visual leaf necrosis in comparison with non-heat stressed well watered trees (Table 6). There was, however, no significant effect of heat stress on the ratio of chlorophyll $\mathrm{a} / \mathrm{b}$ (Table 6$)$. The influence of penconazole $(0.15,0.30$, or $0.45 \mathrm{~g}$ per liter of water) applied immediately after heat stress on the pattern of recovery over the following twelve weeks is shown diagrammatically for chlorophyll fluorescence Fo and leaf electrolyte leakage values (Figure 1). The pattern of recovery for these two parameters reflects those recorded for chlorophyll fluorescence Fv/Fm emissions, total foliar chlorophylls, leaf photosynthetic rates $(\mathrm{Pn})$ and visual leaf necrosis (data not shown). Namely, irrespective of treatment (with or without penconazole), all parameters began to recover. Penconazole treated trees were the most capable of recovery (Figure 1). With respect to chlorophyll fluorescence Fo and leaf electrolyte leakage values recovery rates of heat damaged trees treated with penconazole ranged from 20\%-50\% higher than nonpenconazole-treated control trees (Figure 1). In all cases nontriazole-treated control trees had the least capacity for recovery (Figure 1). Foliar application of penconazole at $30 \mathrm{~g}$ per liter of water induced greatest recovery rates over the 12-week period. At Week 12, all values of penconazole-treated trees were statistically comparable with wellwatered non-heat stressed trees. During the 12 week recovery phase new leaf formation was observed at ca. Weeks 4-6 on both nonpenconazole-treated control and penconazole-treated trees.

Application of penconazole had a marked impact on regeneration from heat stress at the cessation of a 12 week recovery period. Regardless of species, height (evergreen oak only), leaf area, root, shoot, and total plant dry weight were, in virtually all instances, significantly $(P<0.05)$ greater than non-

Table 6. The effects of heat stress $\left(50^{\circ} \mathrm{C}\right)$ for 10 minutes on alterations to plant physiology of evergreen oak (Quercus ilex) and Scots pine (Pinus sylvestris). Measurements were made 24 hours after the cessation of the heat treatment.

\begin{tabular}{|c|c|c|c|c|}
\hline & Quercus ilex & & Pinus sylvestris & \\
\hline Parameter & $\begin{array}{l}\text { Nonpenconazole } \\
\text { Treated control }\end{array}$ & Well-Watered & $\begin{array}{l}\text { Nonpenconazole } \\
\text { Treated control }\end{array}$ & Well-Watered \\
\hline$\%$ electrolyte leakage & $26.7 b$ & $5.14 \mathrm{a}$ & $32.7 b$ & $4.56 \mathrm{a}$ \\
\hline $\mathrm{Fv} / \mathrm{Fm}$ & $0.35 \mathrm{a}$ & $0.83 b$ & $0.28 \mathrm{a}$ & $0.81 b$ \\
\hline Fo & $500.6 b$ & $225.3 a$ & $221.3 b$ & $92.3 \mathrm{a}$ \\
\hline Pn & $2.22 \mathrm{a}$ & $4.21 \mathrm{~b}$ & $1.80 \mathrm{a}$ & $4.00 \mathrm{~b}$ \\
\hline Leaf necrosis & $2.5 b$ & $0.0 \mathrm{a}$ & $3.0 \mathrm{~b}$ & $0.0 \mathrm{a}$ \\
\hline Total chlorophylls & $40.5 \mathrm{a}$ & $82.0 \mathrm{~b}$ & $22.3 \mathrm{a}$ & $45.6 b$ \\
\hline
\end{tabular}

$\%$ electrolyte leakage, photosynthetic rates $(\mathrm{Pn})$ values mean of 10 trees, two leaves per tree.

$\mathrm{Fv} / \mathrm{Fm}$, Fo, total chlorophyll $(\mu \mathrm{g} / \mathrm{g}$ fresh leaf weight), values mean of 10 trees, five leaves per tree.

Leaf necrosis mean of 10 trees.

Lower case letters indicate significant differences in rows between means by LSD at $(P<0.05)$. 
penconazole-treated controls but not as great as well-watered plants which had the greatest growth (leaf area, root, shoot, total plant dry weight; Tables 7-8). Irrespective of concentration applied, foliar application of penconazole had no significant influence on the root:shoot ratio compared to nonpenconazoletreated control trees and well-watered plants (Tables 7-8).

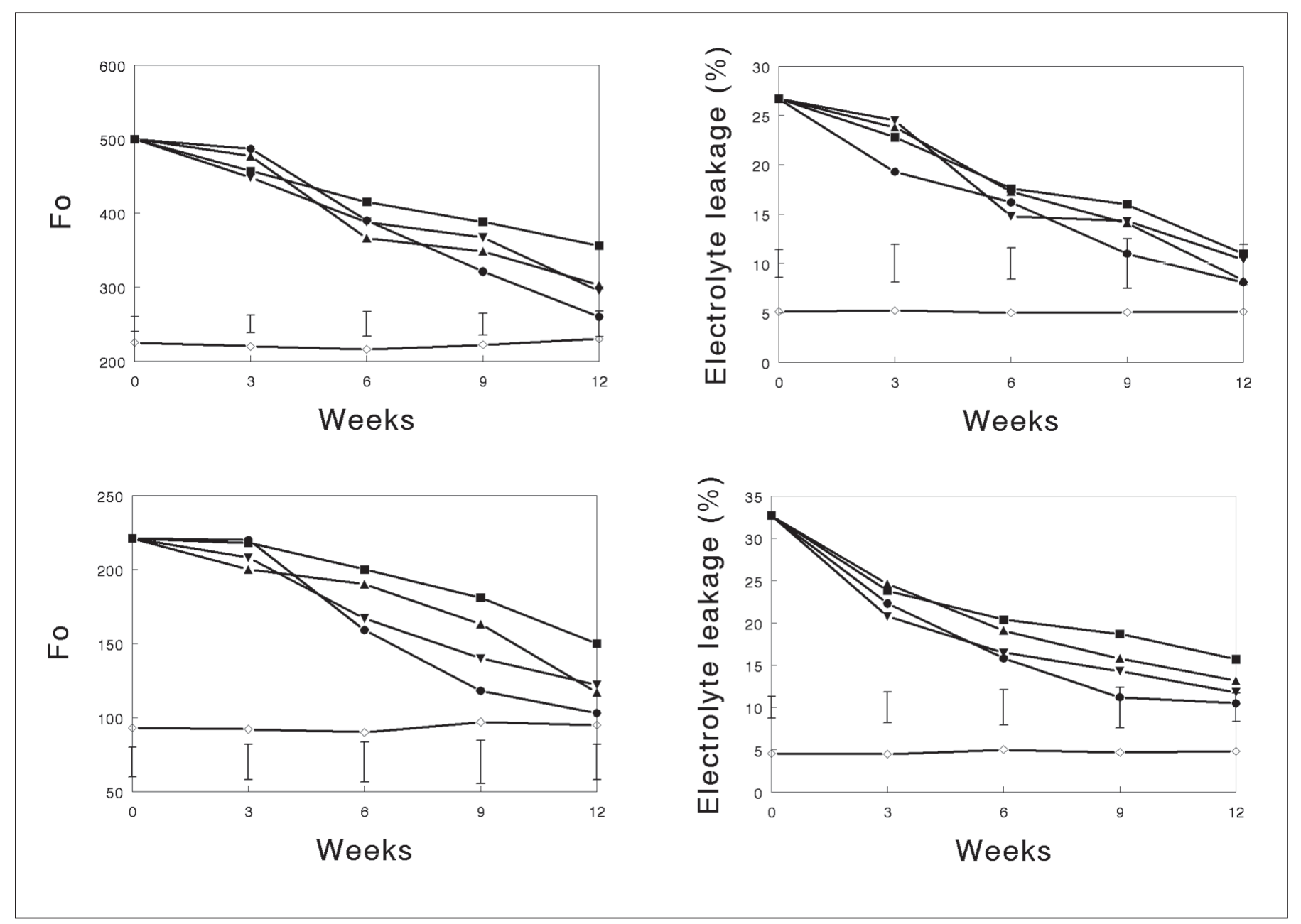

Figure 1. The influence of penconazole on time course recovery over 12 weeks of chlorophyll fluorescence Fo values as a measure of stability of the chlorophyll a/b light-harvesting complex within photosystem II and leaf electrolyte leakage as a measure of cellular membrane integrity of evergreen oak (Quercus ilex) and Scots pine (Pinus sylvestris) following heat stress $\left(50^{\circ} \mathrm{C}\right.$ ) for 10 minutes. Error bars $=$ Least Significant Difference at $P<0.05$., $\square=$ Nontriazole-treated controls, $O=$ Well-watered trees, $\Delta=$ penconazole $15 \mathrm{~g}$ liter of water, - = penconazole $30 \mathrm{~g}$ liter of water, $\nabla=$ penconazole $45 \mathrm{~g}$ liter of water. All values mean of 10 trees. Fo values mean of five leaves per tree, leaf electrolyte leakage values mean of two leaves per tree.

Table 7. The influence of penconazole on growth of containerized evergreen oak (Quercus ilex) at the end of a 12-week recovery period following the cessation of heat induced damage $\left(50^{\circ} \mathrm{C}\right)$ for 10 minutes.

\begin{tabular}{|c|c|c|c|c|c|}
\hline Parameter & $\begin{array}{l}\text { Nontriazole } \\
\text { Treated control }\end{array}$ & $\begin{array}{l}\text { Penconazole } \\
(0.15 \mathrm{~g})\end{array}$ & $\begin{array}{l}\text { Penconazole } \\
(0.30 \mathrm{~g})\end{array}$ & $\begin{array}{l}\text { Penconazole } \\
(0.45 \mathrm{~g})\end{array}$ & Well-Watered \\
\hline Height (cm) & $120.4 \mathrm{a}$ & $125.6 \mathrm{ab}$ & $126.3 \mathrm{ab}$ & $130.4 \mathrm{ab}$ & $135.7 b$ \\
\hline Leaf Area $\left(\mathrm{cm}^{2}\right)$ & $1109 a$ & $1223 \mathrm{ab}$ & $1435 \mathrm{c}$ & $1392 b c$ & $1488 \mathrm{c}$ \\
\hline Root DW (g) & $14.5 \mathrm{a}$ & $19.6 b$ & $18.7 \mathrm{~b}$ & $20.5 b c$ & $23.4 \mathrm{c}$ \\
\hline Shoot DW (g) & $28.7 \mathrm{a}$ & $33.4 \mathrm{ab}$ & $35.8 \mathrm{~b}$ & $38.6 b c$ & $44.6 \mathrm{c}$ \\
\hline Total Plant DW & $43.2 \mathrm{a}$ & $53.0 \mathrm{~b}$ & $54.5 b$ & $59.1 \mathrm{~b}$ & $68.0 \mathrm{c}$ \\
\hline Root:Shoot Ratio & $0.51 \mathrm{a}$ & $0.58 \mathrm{a}$ & $0.52 \mathrm{a}$ & $0.53 \mathrm{a}$ & $0.52 \mathrm{a}$ \\
\hline
\end{tabular}

All values mean of 10 trees.

Lower case letters indicate significant differences in rows between means by LSD at $(P<0.05)$. 
Table 8. The influence of penconazole on growth of containerized Scots pine (Pinus sylvestris) at the end of a 12-week recovery period following the cessation of heat induced damage $\left(50^{\circ} \mathrm{C}\right)$ for 10 minutes.

\begin{tabular}{|c|c|c|c|c|c|}
\hline Parameter & $\begin{array}{l}\text { Nontriazole } \\
\text { Treated control }\end{array}$ & $\begin{array}{l}\text { Penconazole } \\
(0.15 \mathrm{~g})\end{array}$ & $\begin{array}{l}\text { Penconazole } \\
(0.30 \mathrm{~g})\end{array}$ & $\begin{array}{l}\text { Penconazole } \\
(0.45 \mathrm{~g})\end{array}$ & Well-Watered \\
\hline Height (cm) & $127.6 \mathrm{a}$ & $130.5 \mathrm{a}$ & $144.6 a$ & $132.8 \mathrm{a}$ & $149.3 \mathrm{a}$ \\
\hline Leaf Area $\left(\mathrm{cm}^{2}\right)$ & $665.7 \mathrm{a}$ & $700.4 a$ & $803.5 \mathrm{ab}$ & $792.4 \mathrm{ab}$ & $855.0 \mathrm{~b}$ \\
\hline Root DW (g) & $11.8 \mathrm{a}$ & $15.0 \mathrm{ab}$ & $15.8 \mathrm{bc}$ & $18.7 \mathrm{c}$ & $17.8 \mathrm{bc}$ \\
\hline Shoot DW (g) & $24.3 \mathrm{a}$ & $30.2 \mathrm{ab}$ & $34.5 b$ & $32.9 \mathrm{~b}$ & $33.9 \mathrm{~b}$ \\
\hline Total Plant DW & $36.1 \mathrm{a}$ & $45.2 \mathrm{ab}$ & $50.3 b$ & $51.6 \mathrm{~b}$ & $51.7 \mathrm{~b}$ \\
\hline Root:Shoot Ratio & $0.49 \mathrm{a}$ & $0.50 \mathrm{a}$ & $0.46 \mathrm{a}$ & $0.56 \mathrm{a}$ & $0.53 \mathrm{a}$ \\
\hline
\end{tabular}

All values mean of 10 trees.

Lower case letters indicate significant differences in rows between means by LSD at $(P<0.05)$

\section{DISCUSSION}

The fungitoxic effectiveness of penconazole against foliar pathogenic fungi such as apple scab and powdery mildew has been confirmed by several workers under laboratory and field conditions (Kenyon et al. 1997; Schnabel and Parisi 1997; Percival and Boyle 2005). Consequently, penconazole is fully approved for foliar pathogen control under UK pesticide legislation (Anonymous 2010). However, all triazoles, to include penconazole, have been shown to confer stress reducing properties in plants with recorded cases of less drought, freezing, and heat-related plant disorders following pre-treatment with these compounds (Gilley and Fletcher 1997; Jaleel et al. 2007a; Manivannan et al. 2007; Percival and Noviss 2008). Results of this study support previous work. Foliar treatment of both Scots pine and evergreen oak with penconazole at $0.15,0.30$, or $0.45 \mathrm{~g}$ a.i per liter of water resulted in significantly less heat induced damage to the leaf photosynthetic system as determined by chlorophyll fluorescence Fo and Fv/Fm emissions as a measure of stability of the chlorophyll a/b light-harvesting complex within photosystem II and leaf photochemical activity respectively. This result indicates pre-treatment with the triazole derivative penconazole would allow both tree species to tolerate a longer, high temperature episode compared to nonpenconazoletreated trees. Likewise, application of penconazole immediately after the cessation of 10 minutes $50{ }^{\circ} \mathrm{C}$ heat stress improved recovery rates of physiological adaptations associated with tree vitality to include chlorophyll fluorescence Fo and Fv/Fm emissions, total foliar chlorophylls, leaf photosynthetic rates, cellular membrane integrity and visual leaf necrosis so that by the end of a 12 week recovery period values in some instances were statistically comparable to those of well watered non-heat stressed trees.

Application of triazoles such as penconazole have been shown to induce synthesis of a range of stress protective enzymes and metabolites within plants to include low-molecular mass antioxidants such as carotenoids (carotenes and xanthophylls), reactive oxygen species (ROS), scavenging enzymes, such as superoxide dismutase, calatase, $\alpha$-tocopherol, ascorbic acid, and compatible solutes such as proline and glycine betaine, which function as osmoprotectants for proteins (Fletcher et al. 2000; Apel and Hirt 2004; Still and Pill 2004; Fernandez et al. 2006; Jaleel et al. 2007b; Jaleel et al. 2008; Percival and Noviss 2008). High activities or naturally inherent concentrations of these stress protective compounds are regarded as key physiological characteristics conferring plant tolerance to environments where sub-optimal growing conditions prevail (e.g., drought, salinity, root de-oxygenation). As a result, penconazoleenhanced concentrations of these compounds would be important contributors to reducing heat damage to the leaf photosynthetic structure (Kraus and Fletcher 1994; Jaleel et al. 2006; Jaleel et al. 2008). Improved tolerance to, and recovery from heat therefore may be explained in part, by penconazole-induced alterations to leaf anti-oxidant, metabolite and enzymatic activity.

Chlorophyll fluorescence Fo and Fv/Fm emissions as a measure of leaf chloroplast stability and photochemical efficiency provide an indirect measure of tree vitality (Clarke et al. 2000). Alterations to these values are sensitive indicators of damage to the leaf photosynthetic system caused by environmental stress (Percival and Sheriffs 2002). After heat exposure at fixed time periods, damage to the leaf photosynthetic system based on the stability of the chlorophyll a/b light-harvesting complex within photosystem II (Fo values) and leaf photochemical efficiency (Fv/Fm emissions) in penconazole-treated trees was significantly less than nonpenconazole-treated trees. The maintenance of relatively high fluorescence values in triazole treated plants under stress has been observed in previous studies (Pinhero and Fletcher 1994) with higher values associated with reduced impairment of leaf photosynthetic activities (Percival et al. 2006). Robustness of the photosynthetic system is an important physiological trait associated with survivability under prolonged environmental stress conditions to ensure carbohydrate production via photosynthesis necessary for the growth and repair of damaged tissue.

Over a 12 -week recover period following a 10-minute heat stress period, vitality of penconazole-treated trees as measured by chlorophyll fluorescence Fo emissions and leaf electrolyte leakage ranged from $20 \%-50 \%$ higher than nonpenconazoletreated trees. Limited studies have recorded the influence of triazoles as an aid toward heat-induced stress recovery. Leaf chlorophyll Fo and electrolyte leakage values were similar to those of well-watered (i.e., nonstressed trees) by week 12 post-recovery, indicating regeneration and full functioning of the leaf photosynthetic system and cell membrane integrity. The importance of rapid recovery from stress has been shown elsewhere (Gilley and Fletcher 1997; Still and Pill 2004), with genotypes that rebound to original or near original physiological levels most likely to survive and tolerate prolonged stress episodes compared to those that do not or are slower to recover (Aguilera et al. 1997; Bauerle and Dudley 2003). In this study, nonpenconazole-treated control trees had the least capacity for recovery because leaf chlorophyll Fo and electrolyte leakage were 45\%-55\% lower at the cessation of the post-heat 12-week recovery period compared to well-watered trees. Improvements in the range of the previously discussed physiological measurements may account for increased growth as measured by height, leaf area, shoot, root, and total plant dry weight in trees treated with penconazole at the end of a post-heat 12-week recovery period (Martin et al. 1987; 
McKay 1992; Cameron and Dixon 1997). Besides maintenance of photosynthetic integrity, prevention of leaf abscission has been shown to be a significant contributor to growth under stress as leaves are the major photosynthetic organ responsible for carbohydrate production required for repair and functioning of damaged leaf tissue (Tyree et al. 1993). Likewise, leaf production rates are important variables influencing growth under environmental stresses (Pregitzer et al. 1990; Farrell et al. 1996). Significantly less leaf loss during the recovery period as stimulated by penconazole application enhanced total leaf area and subsequent photosynthetic area necessary for growth (Farrell et al. 1996). Indeed productivity as measured by total tree dry weight has been correlated with net photosynthetic rates (Ort and Boyer 1985).

In conclusion, heat stress is recognized as a problematic factor that indirectly through leaf and wood desiccation may contribute to branch shed and tree decline in urban landscapes (Hitchmough 1994). The tactical use of the triazole derivative penconazole as an ameliorant against heat damage and recovery from heat stress in woody plants would be of benefit to improve tree recovery rates and growth of Scots pine and evergreen oak. From a practical point of view penconazole at $30 \mathrm{~g}$ a.i. per liter of water is suggested based on the results of this study.

\section{LITERATURE CITED}

Aguilera, C., C.M. Stirling, and S.P. Long. 1997. Genotypic variation within Zea mays for susceptibility to and rate of recovery from chill-induced photoinhibition of photosynthesis. Physiol Plantarum 106:429-436.

Allingham, R. 2005. The effect of the growth retardant paclotutrazol on the in vitro growth and development of Betula and Populus species. MSc Thesis, Dept of Environmental Management, University of Central Lancashire.

Apel, K., and H. Hirt. 2004. Reactive oxygen species: metabolism, oxidative stress, and signal transduction. Annual Review Plant Biology 55:373-399.

Asare-Boamah, N.K., G. Hofstra, R.A. Fletcher, and E.B. Dumbroff. 1986. Triadimefon protect bean plants from water stress through its effect on abscisic acid. Plant Cell Physiology 27:383-390.

Anonymous. 2010. The UK Pesticide Guide. British Crop Protection Council, Cabi Publishing: Oxon, UK.

Bauerle, W.L., and J.B. Dudley. 2003. Genotypic variability in photosynthesis, water use, and light absorption among red and freeman maple cultivars in response to drought stress. Journal American Society Horticultural Science 128:337-342.

Cameron R.W.F., and G.R. Dixon. 1997. Air temperature, humidity and rooting volume affecting freezing injury to Rhododendron and other perennials. Journal Horticultural Science Biotechnology 72(4): $553-562$.

Clark, A.J., W. Landolt, J. Bucher, and R.J. Strasser. 2000. Beech (Fagus sylvatica $\mathrm{L}$.) response to ozone exposure assessed with a chlorophyll a fluorescence performance index. Environmental Pollution 109:501-507.

Cajanek, M., M. Stroch, I. Lachetova, J. Kalina, and V. Spunda. 1998. Characterization of the photosystem II inactivation of heat stressed barley leaves as monitored by the various parameters of chlorophyll a fluorescence and delayed fluorescence. Journal Photochemistry Photobiology 47:39-45.

Farrell, R.C.C., D.T. Bell, K. Akilan, and J.K. Marshall. 1996. Morphological and physiological comparisons of clonal lines of Eucalyptus camaldulensis. II. Responses to waterlogging/salinity and alkalinity. Austrian Journal Plant Physiology 23:509-518.

Fernandez, J.A., L. Balenzategui, S. Banon, and J.A. Franco. 2006. Induction of drought tolerance by paclobutrazol and irrigation deficit in Phillyrea angustifolia during the nursery period. Scientia Horticulturae 107:277-283.

Fletcher, R.A., G. Hofstra, and J. Gao. 1986. Comparative fungitoxic and plant growth regulating properties of triazole derivatives. Plant Cell Physiology 27:367-371.

Fletcher, R.A., A. Gilley, N. Sankhla, and T.D. Davis. 2000. Triazoles as plant growth regulators and stress protectants. Horticultural Review 24:55-138.

Georgieva., K., T. Tsonev, V. Velikova, and I. Yordanov. 2000. Photosynthetic activity during high temperature of pea plants. Journal Plant Physiology 157:169-176.

Gilley, A., and R.A. Fletcher. 1997. Relative efficacy of paclobutrazol, propiconazole and tetraconazole as stress protectants in wheat seedlings. Journal Plant Growth Regulators 21:169-175.

Harris, R.W., J.R. Clark, and N.P. Matheny. 2004. Arboriculture: Integrated Management of Landscape Trees, Shrubs and Vines. 4th Edition, Publ Prentice-Hall. New York.

Hitchmough, J.D. 1994. Urban Landscape Management. Publ Inkata Press: Sydney, Australia. Chapter 5, 114-121 pp

Hong, S.S., and D-Q. Xu. 1999. Light-induced increase in chlorophyll fluorescence Fo level and the reversible inactivation of PSII reaction centers in soybean leaves. Photosynthesis Research 61:269-280.

Jaleel, C.A., R. Gopi, G.M. Alagu Lakshmanan, and R. Panneerselvam. 2006. Triadimefon induced changes in the antioxidant metabolism and ajmalicine production in Paclobutrazol enhances photosynthesis and ajmalicine production in Catharanthus roseus (L.). Plant Science 171:271-276.

Jaleel, C.A., P. Manivannan, B. Sankar, A. Kishorekumar, S. Sankari, and R. Panneerselvam. 2007a. Paclobutrazol enhances photosynthesis and ajmalicine production in Catharanthus roseus. Process Biochemistry 42:1566-1570.

Jaleel, C.A., R. Gopi, P. Manivannan, A. Kishorekumar, R. Sridharan, and R. Panneerselvam. 2007b. Studies on germination, seedling vigour, lipid peroxidation and proline metabolism in Catharanthus roseus seedings under salt stress. South African Journal Botany 73:190-195.

Jaleel, C.A., R. Gopi, P. Manivannan, M. Gomathinayagam, P.V. Murali, and R. Panneerselvam. 2008. Soil applied propiconazole alleviates the impact of salinity on Catharanthus roseus by improving antioxidant status. Pesticide Biochemistry and Physiology 90(2):135-139.

Kenyon, D.M., G.R. Dixon, and S. Helfer. 1997. The repression and stimulation of growth of Erysiphe sp. on Rhododendron by fungicidal compounds. Plant Pathology 46:425-431

Kolb, P.F., and R. Robberecht. 1996. High temperature and drought stress effects on survival of Pinus ponderosa seedlings. Tree Physiology 16:665-672.

Kraus, T.E., and R.A. Fletcher. 1994. Paclobutrazol protects wheat seedlings from heat and paraquat injury. Is detoxification of active oxygen involved? Plant Cell Physiology 35:45-52.

Ladjal, M., D Epron, and M Ducrey. 2000. Effects of drought preconditioning on thermotolerance of photosystem II and susceptibility of photosynthesis to heat stress in cedar seedlings. Tree Physiology 20:1235-1241.

Levene, H. 1960. Robust tests for equality of variances. In: Contributions to Probability and Statistics. W.G. Madow and H.B. Mann (Eds.). Stanford University Press: Stanford, California. 
Lichtenthaler, H.K., and A.R. Wellburn. 1983. Determinations of total carotenoids and chlorophylls a and b of leaf extracts in different solvents. Biochemistry Society Transmycology 11:591-593.

McKay, H. 1992. Electrolyte leakage from fine roots of conifer seedlings: a rapid index of plant vitality following cold storage. Canadian Journal Forest Research 22:1371-1377.

Manivannan. P., C.A. Jaleel, A. Kishorekumar, B. Sankar, R. Somasundaram, R. Sridharan, and R. Panneerselvam. 2007. Propiconazole induced changes in antioxidant metabolism and drought stress amelioration in Vigna unguiculata (L.) Walp. Colloids surf. B: Biointerfaces 57:69-74.

Marshall, J.G., R.G. Rutledge, E. Blumwald, and E.B. Dumbroff. 2000. Reduction in turgid water volume in jack pine, white spruce and black spruce in response to drought and paclobutrazol. Tree Physiology 20:701-707.

Martin, U., S.G. Pallardy, and Z.A. Bahari. 1987. Dehydration tolerance of leaf tissues of six woody angiosperm species. Physiol Plantarum 69:182-186.

Maxwell, K., and G.N. Johnson. 2001. Chlorophyll fluorescence - A practical guide. Journal Experimental Botany 51:659-668.

Ort, D.R., and J.S. Boyer. 1985. Plant productivity, photosynthesis, and environmental stress. In Changes in Gene Expression in Response to Environmental Stress. B.C. Atkinson and D.B. Walden (Eds.). Academic Press: New York. pp. 279-311.

Percival, G.C., and C. Sheriffs. 2002. Identification of drought tolerant woody perennials using chlorophyll fluorescence. Journal Arboriciculture 28:215-224.

Percival, G.C. 2005. Identification of foliar salt tolerance of woody perennials using chlorophyll fluorescence. Hortscience 40(6):1892-1897.

Percival, G.C., and S. Boyle. 2005. Evaluation of microcapsule trunk injections for the control of apple scab and powdery mildew. Annals of Applied Biology 147:119-127.

Percival, G.C. 2008. Paclobutrazol soil drenches provide partial reductions in symptoms of apple scab of ornamental trees and Guignardia leaf blotch of horse chestnut. Journal of Environmental Horticulture 26(2):81-87.

Percival, G.C., I.P. Keary, and A.L. Habsi Sulaiman. 2006. An assessment of the drought tolerance of Fraxinus genotypes for urban landscape plantings. Urban Forestry Urban Greening 5:17-27.

Percival, G.C., and K. Noviss. 2008. Triazole induced drought tolerance in horse chestnut (Aesculus hippocastanum) Tree Physiology. 28(11):1685-1692.

Pinhero, R., and R. Fletcher. 1994. Paclobutrazol and ancymidol protect corn seedlings from high and low temperature stress. Plant Growth Regulators 15:47-53.
Pregitzer, K.S., D.L. Dickmann, R. Hendrick, and P.V. Nguyen. 1990. Whole-tree carbon and nitrogen portioning in young hybrid poplars. Tree Physiology 7:79-93.

Schnabel, G., and L. Parisi. 1997. Sensitivity of Venturia inaequalis to five DMI fungicides, including the new triazole fluquinconazole, and to pyrimethanil. Journal Plant Disease Protection 104:36-46.

Sprugel, D.G., T.M. Hinckley, and W Schaap. 1991. The Theory and Practice of Branch Autonomy - Annual Review of Ecology 22: 309-334.

Still, J.R., and W.G. Pill. 2004. Growth and stress tolerance of tomato seedlings (Lycopersicon esculentum Mill.) in response to seed treatment with paclobutrazol. Journal Horticultural Science Biotechnology 79:197-203.

Tyree, M.T., H. Cochard, P. Cruiziat, B. Sinclair, and T. Ameglio. 1993. Drought-induced leaf shedding in walnut: evidence for vulnerability segmentation. Plant Cell Environment 16:879-882.

Von Caemmerer, S., and G.D. Farquhar 1981. Some relationships between the biochemistry of photosynthesis and the gas exchange of leaves. Planta 153:376-387.

Watson, G.W. 2001. Soil application paclobutrazol affects root growth, shot growth, and water potential of American elm seedlings. Environmental Horticulture 19:119-122.

Willits, D.H., and M.M. Peet. 2001. Using chlorophyll fluorescence to model leaf photosynthesis in greenhouse pepper and tomato. Acta Horticulturae 507:311-315.

Yamane, Y., T. Shikanai, Y. Kashino, H. Koike, and K. Satoh. 2000. Reduction of QA in the dark: Another cause of fluorescence Fo increases by high temperatures in higher plants. Photosynthesis Research $63: 23-34$

Glynn C. Percival (corresponding author)

Bartlett Tree Research Lab

University of Reading - Biological Sciences

2 Earley Gate

Whiteknights Berkshire, Reading RG6 6AU

United Kingdom

Kelly Noviss

Bartlett Tree Research Lab

University of Reading - Biological Sciences

Reading, United Kingdom 
Résumé. La capacité du penconazole - un dérivé du fongicide triazole - à protéger les arbres contre le stress de la chaleur et même à améliorer cette tolérance a été étudiée chez le chêne vert (Quercus ilex) et le pin sylvestre (Pinus sylvestris). Sous des conditions de laboratoire, les dommages par la chaleur au système photosynthétique foliaire à partir des feuilles des feuilles tombées était constamment inférieur chez les arbres traités au penconazole, et ce en se basant sur le complexe de lumière récoltée par la stabilité de la chlorophylle a/b à l'intérieur du photosystème II (réponses à la fluorescence de la chlorophylle Fo) et l'efficacité photochimique foliaire (émissions de fluorescence de la chlorophylle Fv/ Fm). Chez les deux espèces, la plus grande protection du système photosynthétique foliaire face aux désordres par la chaleur a été atteinte par l'application de penconazole à une concentration de $30 \mathrm{~g}$ par litre d'eau comparativement à des concentrations de 0,15 ou $0,45 \mathrm{~g}$ par litre d'eau. La soumission des deux espèces arbres en contenant durant 10 minutes à des émissions de température de $50^{\circ} \mathrm{C}$ a significativement diminué la vitalité des arbres selon les émissions de fluorescence de la chlorophylle Fo et $\mathrm{Fv} / \mathrm{Fm}$, la chlorophylle foliaire totale, les taux de photosynthèse foliaire (Pn) et a aussi significativement accru les dommages à l'intégrité des membranes cellulaires qui se manifestaient par une perte plus élevée d'électrolytes foliaires ainsi qu'une nécrose foliaire visuelle entre les arbres stressés par rapport aux arbres non stressés par la chaleur et bien arrosés. L'influence du penconazole appliqué immédiatement après un stress de chaleur, et ce en regard du patron de reprise durant les douze semaines qui suivirent démontrèrent que les arbres traités au penconazole étaient ceux qui étaient le plus apte à se remettre. Selon les valeurs de fluorescence de la chlorophylle Fo et de perte en électrolytes, les taux de reprise des arbres endommagés par la chaleur et traités avec le penconazole étaient de $20 \%$ à $50 \%$ plus élevés que les arbres non traités du groupe-témoin. Dans tous les cas, les arbres-témoin non traités au penconazole avaient la plus faible capacité de reprise. Peu importe l'espèce, la hauteur, la surface foliaire ainsi que la masse sèche en racines, pousses et totale de la plante étaient dans la plupart des cas plus élevées chez les arbres traités que ceux non traités. L'utilisation tactique du penconazole, un dérivé du triazole, comme agent pour améliorer la résistance face à la chaleur ainsi que le degré de reprise par la suite chez le chêne vert le pin sylvestre pourrait être bénéfique pour améliorer le taux de reprise et la croissance. D'un point de vue pratique, le penconazole à un taux de $30 \mathrm{~g}$ d'ingrédient actif par litre d'eau est suggéré si on se base sur les résultats de cette recherche.

Zusammenfassung. Die Fähigkeit von Penconazol, einem TriazolFungizid Derivat zum Schutz gegen Hitzestress wurde bei Immergrünen Eichen (Quercus ilex) und Waldkiefer (Pinus sylvestris) getestet. Unter Laborbedingungen basierte der Hitzeschaden am Blattphotosynthesesytem auf der Stabilität des Chlorophyll a/b Lichternte-Komplexes innerhalb des Photosystems II (Chlorophyll Fluoreszenz Fo Resonanz) und die photochemische Effizienz der Blätter (Chlorophyll Fluoreszenz Fv/ Fm Emissionen) bei abgenommenen Blättern war konstant weniger als in mit Penconazol behandelten Bäumen. Bei beiden Arten war der größte Schutz des Blattphotosynthesesystems durch hitze-induzierte Schäden durch die Applikation von Penconazol in einer Konzentration von 30 g pro Liter Wasser im Vergleich zur Applikation von 0,15 oder $0,45 \mathrm{~g} / \mathrm{l}$ Wasser erreicht. Wurden Containerpflanzen beider Arten für 10 Minuten $50^{\circ} \mathrm{C}$ ausgesetzt, reduzierte sich die Vitalität im Hinblick auf Chloro- phyll Fluoreszenz Fo und Fv/Fm Emissionen, totalem Blattchlorophyllgehalt und die Blattphotosyntheseraten (Pn) deutlich, während verstärkt Schäden auftraten an zellulären Membranen und ihrem Zusammenhalt als Manifest höheren Blattelektrolyt-Austritts und sichtbarer Blattnekrose zwischen gestressten und ungestressten, gut gewässerten Bäumen. Der Einfluss von direkt nach dem Hitzestress applizierten Penconazol auf die Art der Genesung der Bäume in den folgenden zwölf Wochen zeigte, daß Penconazol-behandelte Bäume sich schnell wieder erholen können. Im Hinblick auf die Chlorophyll Fluoreszenz Fo und die Blattelektrolyt-Austrittswerte rangierten die Erholungsraten von hitzegeschädigten, mit Penconazol behandelten Bäumen um 20\%-50 \% höher als die nicht mit Triazol behandelten Kontrollbäume. In allen Fällen hatten die nicht mit Penconazol behandelten Bäume die schlechtesten Erholungsraten. Unabhängig von der Art, war die Höhe, Blattfläche, Wurzeln, Triebe und totales Pflanzentrockengewicht, virtuell in allen Instanzen, größeer als bei unbehandelten Kontrollbäumen. Der taktische Einsatz des Triazolderivats Penconazol als ein Verbesserer im Einsatz gegen Hitzeschäden und zur Erholung von Hitzestress bei Waldkiefer und Immergrünen Eichen würde einen positiven Beitrag zur Verbesserung von Erholungsraten und Wachstumsraten von Bäumen leisten.

Resumen. Se estudió la habilidad de penconazole, un fungicida derivado del triazol, para proteger contra stress por calor en encinos verdes (Quercus ilex) y pinos Scots (Pinus sylvestris). Bajo condiciones de laboratorio, el daño por calor al sistema fotosintético de la hoja basado en la estabilidad de la clorofila a/b dentro del fotosistema II (respuestas clorofila fluorescente Fo) y la eficiencia fotoquímica de la hoja (emisiones Fv/ Fm clorofila fluorescente) de hojas aisladas fue constantemente menor en árboles tratados con penconazole. En ambas especies, la protección mayor del sistema fotosintético al calor indujo desórdenes que fueron alcanzados por la aplicación de penconazole a una concentración de $30 \mathrm{~g}$ por litro de agua comparado a penconazole aplicado a concentración de 0.15 o $0.45 \mathrm{~g}$ por litro de agua. Al someter árboles en contenedor de ambas especies 10 minutos a $50^{\circ} \mathrm{C}$ se redujo significativamente la vitalidad del árbol con respecto a la clorofila fluorescente Fo y las emisiones Fv/ Fm, clorofila total foliar, tasas fotosintéticas de la hoja (Pn) e incrementó significativamente el daño a la integridad de la membrana celular como efecto de mayor pérdida de electrolitos foliares y necrosis foliar visual entre estresados y no estresados por calor de árboles bien regados. La influencia de penconazole aplicado inmediatamente después del estrés en patrones de recobramiento en las doce semanas siguientes demostró que los árboles tratados con penconazole fueron más capaces de recobrarse. Con respecto a la clorofila fluorescente Fo y la pérdida de electrolitos los valores se recobraron a tasas de árboles tratados por daños por el calor con penconazole varió de 20\%-50\% más altos que árboles de control no tratados. En todos los caso los árboles de control no tratados con penconazole tuvieron la menor capacidad para recobrarse. Sin importar la especie, altura, área foliar, raíz, brotes, peso seco total de la planta fueron, virtualmente en todos los casos, mayores que los controles no tratados. El uso táctico de triazol derivado de penconazole como un tratamiento contra el daño por calor y recobramiento del estrés en pino Scots y encino podría ser de beneficio para mejorar los árboles y la tasa de crecimiento. Desde el punto de visto práctico se sugiere el penconazole a una tasa de $30 \mathrm{~g}$ por litro de agua con base en los resultados de este estudio. 